\title{
Effect of Foliar Feeding of Plant Growth Regulators on Vegetative Growth, Yield and Quality of Phalsa (Grewia subinaequalis DC)
}

\author{
Sukhjit Kaur* \\ Punjab Agricultural University, Regional Research Station, \\ Gurdaspur(Punjab)-143521, India \\ *Corresponding author
}

\begin{tabular}{|l|}
\hline Ke y w o r d s \\
Plant growth \\
regulators, \\
$\begin{array}{l}\text { Foliar feeding, } \\
\text { Yield and quality }\end{array}$ \\
\hline Article Info \\
\hline $\begin{array}{l}\text { Accepted: } \\
\text { 21 May 2020 } \\
\text { Available Online: } \\
\text { 10 June 2020 }\end{array}$ \\
\hline
\end{tabular}

Keywords

Plant growth regulators,

Foliar feeding Yield and quality

Accepted:

21 May 2020

10 June 2020

\begin{abstract}
A B S T R A C T
A field experiment was carried out at Punjab Agricultural University, Regional Research Station, Gurdaspur during the years 2015-16 and 2016-17 to assess the influence of NAA $25,50 \mathrm{ppm}$ and $75 \mathrm{ppm} ; \mathrm{GA}_{3} 50,100 \mathrm{ppm}$ and $150 \mathrm{ppm}$; kinetin 15,30 and $45 \mathrm{ppm}$; ethrel $250,500 \mathrm{ppm}$ and $750 \mathrm{ppm}$ along with control on vegetative growth, yield and quality parameters of phalsa. Among all the treatments, maximum number of shoots/ plant (130.25), shoot length $(4.15 \mathrm{~cm})$, number of leaves $/$ shoot $(72.5)$, internodal length $(11.5 \mathrm{~cm})$, number of fruits/ node (21.55) and number of fruiting nodes/ shoot (20.76) were recorded with the application of $\mathrm{GA}_{3}$ at $150 \mathrm{ppm}$. Maximum fruit yield $(4.85 \mathrm{~kg} / \mathrm{plant})$, fruit length $(1.60 \mathrm{~cm})$. Fruit breadth $(1.72 \mathrm{~cm})$ and pulp weight $(65.55 \mathrm{gm})$ were observed in $\mathrm{GA}_{3}$ at $100 \mathrm{ppm}$. Minimum stone weight $(10.22 \mathrm{~g})$ with maximum pulp to stone ratio (37.89) was observed in $\mathrm{GA}_{3} 100 \mathrm{ppm}$. Maximum TSS $\left(27.50^{\circ}\right.$ Brix) with minimum titratable acidity $(2.3 \%)$ were observed with ethrel $500 \mathrm{ppm}$. Maximum TSS to acidity ratio (11.96) was obtained with ethrel 500ppm. Total sugars $(29.00 \%)$, reducing sugars $(21.50 \%)$ and nonreducing sugars $(7.50 \%)$ were significantly higher in ethrel $750 \mathrm{ppm}$. Highest ascorbic acid content $\left(44.25 \mathrm{mg} / 100 \mathrm{gm}\right.$ of pulp) was noticed in $\mathrm{GA}_{3}$ 100ppm.Maximum shelf life (53.51hours) of fruits was observed with kinetin 30ppm.
\end{abstract}

\section{Introduction}

The Phalsa (Grewia subinaequalis DC) also known as star apple, it is a sub-tropical fruit native to India, belongs to the family Tiliaceae with chromosome no. $2 \mathrm{n}=36$. This family has about 41 genera and 400 species, which are mostly distributed in the tropical and sub-tropical region of the world. Its fruit is known as berry. Phalsa is a quick growing shrub which thrives well in arid and semi-arid regions as well as in salt affected wasteland conditions because of its hardy nature and capacity to tolerate high temperature and even to be grown under prolonged dry spells (Singh et al., 2011). India is considered to be the home of phalsa and it is grown in Punjab, Haryana, Rajasthan, Uttar Pradesh, Madhya Pradesh, Bihar and West Bengal (Zeeshan and Singh, 2017). In Punjab, it is mostly grown in 
Ropar, Hoshiarpur, Gurdaspur and Amritsar districts. The area under phalsa in Punjab is only 30 hectares with an annual production of 196 tonnes (Pujari, 2015). Ripe phalsa fruits are deep reddish brown colour, sub acidic in taste, pleasant flavour, rich source of vitamins (A, C) and minerals (phosphorus and iron). Fruit contains protein $1.3 \mathrm{~g}$, fat $0.9 \mathrm{~g}$, carbohydrates $14.7 \mathrm{~g}$, fibre $1.2 \mathrm{~g}$, minerals $1.1 \mathrm{~g}$, phosphorus $39 \mathrm{mg}$, calcium $129 \mathrm{mg}$, iron $3.1 \mathrm{mg}$, carotene $0.48 \mathrm{mg}$, niacin $0.3 \mathrm{mg}$ and vitamin C $22 \mathrm{mg}$ per $100 \mathrm{gm}$ of pulp.. The energy value is $300 \mathrm{cal} / 100 \mathrm{~g}$. The fruits are very delicious, tasty and used as table purpose. The fruits are excellent for making juice and squash, quality beverages, ready to serve, nectar, syrup. The ripe phalsa fruits are consumed fresh, as desserts or processed into refreshing fruit and soft drinks enjoyed during summer months in India (Salunkhe and Desai, 1984). Its cultivation is favoured around big cities where fruits find a read and quick sale. Regarding keeping quality, it is highly perishable in nature. Because of short shelf life, its fruits are suitable for local market or need to be processed immediately after harvesting (Salunkhe and Desai, 1984). It may be grown as an intercrop with mango, aonla, bael and ber. Phalsa is a bushy plant and can be grown in kitchen garden also. It produces fruits in clusters in the axil of leaves of the current season growth. Despite its hardy fruits, high nutritional and medicinal values, phalsa has not received the deserving attention due to its uneven ripening, small fruits and high perishability creating a problem in marketing and storage. Growth, yield and quality of phalsa can be increased by adopting proper cultural practices, supplying balanced doses of nutrients and through use of growth regulators. The plant growth regulators are relatively new in use. Plant growth regulators are chemicals that effect root growth, prevention and promotion of stem elongation, flowering, ageing and color enhancement of phalsa fruits. A very small concentration of these substances produces major growth changes. They are widely used for increasing fruit set, controlling fruit drop, enhancing quality and uniform maturity. Among growth regulators gibberellic acid $\left(\mathrm{GA}_{3}\right)$, 1-Naphthalene acetic acid(NAA), ethrel, kinetin are widely used for enhancing superior characters of the fruit crop. Application of growth substances viz., auxins and gibberellins has been effective in increasing fruitset and yield in several fruit crops including phalsa (Randhawa et al., 1959). Gibberellic acid is an important plant growth substance which plays a vital role on overall performance including growth, flowering and quality of fruits. It increases cell division and cell elongation in the plants. Application of $\mathrm{GA}_{3}$ results in increased yield and better grade of phalsa (Debnath et al., 2011). The use of bioregulator like $\mathrm{GA}_{3}$ has proved effective for increasing the size of berry or fruit and improved quality in crop like grape, citrus, beretc (Kacha et al., 2012). Parthenocarpic development of fruits is also a result of gibberellins action (Krishnamoorthy, 1981). Application of $\mathrm{GA}_{3}$ results in increased yield and better grade phalsa fruits (Randhawa et al., 1967). NAA is widely used in horticulture for various purposes and play many important roles in flowering, fruit setting and tissue culture, increase in fruit set or prevent fruit drop in mango and citrus, blossom thinning in peach and guava and fruit thinning in apple and pear.It is thought that NAA may influence the rate of metabolic activity of developing embryoes and even also stimulate ethylene biosynthesis which inhibits fruit growth and promote the abscission of weaker fruits. Naphthalene acetic acid shows positive attitude towards the reduction of fruit drop in many fruit crops. Application of ethrel improves fruit quality in terms of total soluble solids (TSS), reducing and total sugar (Kacha et al., 2014). Ethrel is a compound that decomposes to release the natural plant hormone ethylene. Its main use 
in fruit production is to enhance fruit ripening by permitting its harvest about one week earlier and also reduces the span of harvesting and number of pickings significantly (Kacha et al., 2014). Ethrel sprayed at full bloom stage found to be increasing TSS content of the phalsa fruits (Rema and Sharma, 1991). The bioregulators have proved to be effective in increasing fruit set and yield in phalsa as well as quality of fruit in terms of TSS, reducing sugars and total sugars. Cytokinin results in the promotion of cell division. Along with auxin, cytokinin initiates bud and root formation in the callus tissue in plant tissue culture. Cytokinin promotes the growth of lateral buds when added in the medium even if the apical bud is intact. Cytokinin breaks the dormancy of seeds and promotes germination. Application of cytokinin delays the process of ageing in plants. Efficacy of kinetin in increasing shelf life by reducing the physiological loss of weight of fruit crops was shown by various workers (Dedolph et al., 1961 and Randhawa et al., 1976).

Nevertheless, a lot of approaches have been made on foliar feeding of plant growth regulators on different fruit crops, however, meagre work has been done on phalsa crop. Keeping the role of bioregulators in view, the present study was carried out for improved growth, fruit set, yield and quality of phalsa.

\section{Materials and Methods}

The present study was under taken at Punjab Agricultural University, Regional Research Station, Gurdaspur, Punjab (India) during the year 2015-16 and 2016-17. The experiment was laid out in a Randomized Block Design with thirteen treatments and replicated thrice. Ten years old, 39 uniform phalsa plants in two units transplanted at $3 \times 3$ meters were selected for present investigation. Manures, fertilizers and other orchard management practices were followed as per recommended package and practices for phalsa. The treatments consisted of NAA $25,50 \mathrm{ppm}$ and $75 \mathrm{ppm} ; \mathrm{GA}_{3}$ 50, $100 \mathrm{ppm}$ and 150ppm; kinetin 15, 30 and $45 \mathrm{ppm}$; ethrel 250, 500 ppm and 750ppm along with control. NAA, $\mathrm{GA}_{3}$ and kinetin were sprayed at fruit set, whereas ethrel was sprayed 20 to 25 days prior to harvesting to find out the optimum concentration of these bioregulators. The observations were recorded on the parameters viz. number of shoots per plant, length of shoot (m), number of leaves per plant, internodal length $(\mathrm{cm})$, number of fruiting nodes per shoot, number of fruits per node, fruit yield per plant $(\mathrm{kg})$, fruit length $(\mathrm{cm})$, fruit breadth $(\mathrm{cm})$, pulp weight $(\mathrm{gm})$, stone weight(gm), pulp:stone ratio, ascorbic acid (mg/100g of pulp), TSS ( ${ }^{\circ}$ Brix), titratable acidity (\%), TSS to acidity ratio, total sugars (\%), reducing sugars (\%), non-reducing sugars, shelf life (hours). Fruits were harvested at fully ripe stage and quality parameters are calculated as per standard AOAC, (1980) methods. Data was analysed statistically by Randomized Block Design as described by Singh et al., (1998) and the effects of treatments were tested at 5 percent level of significance.

\section{Results and Discussion}

\section{Number of shoots/plant}

Number of shoots per plant was also influenced significantly by the application of plant growth regulators.However, the maximum (130.25) number of shoots per plant was measured with foliar spray of $\mathrm{GA}_{3} 150 \mathrm{ppm}$ followed with the spray of $\mathrm{GA}_{3} 100 \mathrm{ppm}$ (Table1). Number of shoot per plant was increased with the application of plant growth regulators spray. Increase in plant growth parameters might be due to fact that gibberellin (given in the form of $\mathrm{GA}_{3}$ sprayed) is a constituent of protein which is essential for formation of protoplasm and 
thus, affecting cell division and cell elongation. All these contributed in enhancing shoot length and number of shoots per plant of phalsa. The present findings are in agreement with the report of Kumar et al., (2014) in phalsa. Positive impact of $\mathrm{GA}_{3}$ application on plant spread and crown volume was recorded by Eelkim et al., (2003) in Satsuma mandarin, where they reported increased number the vegetative shoots in response to progressive increase in the doses of treatments $(25,50$ and $100 \mathrm{ppm}$ concentrations of $\mathrm{GA}_{3}$ ).

\section{Shoot length}

Foliar spray of plant growth regulators significantly effect the shoot length. However, the maximum shoot length $(4.15 \mathrm{~m})$ was measured with foliar spray of $\mathrm{GA}_{3} 150 \mathrm{ppm}$ followed by spray of $\mathrm{GA}_{3} 100$ ppm (Table1). Similar results has been reported by Alam and Kumar, (2017) and Singh et al., (2017) that maximum shoot length was observed in phalsa with foliar spray of $\mathrm{GA}_{3} 150 \mathrm{ppm}$. The increase in vegetative growth of the phalsa plant with the spray of plant growth regulators may be attributed to the association of nitrogen in the synthesis of protoplasm and in the primary manufacture of amino acids and increased auxin activities. As a result, meristematic activities increased which in increase the vegetative growth.

\section{Number of leaves per shoot}

The number of leaves per shoot increased significantly with the application of foliar feeding of plant growth regulators. Highest number of leaves (72.5) was obtained with foliar spray of $\mathrm{GA}_{3}$ 150ppm followed by $\mathrm{GA}_{3} 100 \mathrm{ppm}$ (Table1). The favourable effect of $\mathrm{GA}_{3}$ in promoting number of leaves might be due to abundant supply of $\mathrm{GA}_{3}$ on plant growth. The increase in vegetative growth may be attributed to an increase uptake of these elements which being a constituent of protein component of protoplasm, favourably influenced chlorophyll content in leaves. All these factors contributed to cell multiplication, which has resulted in to better photosynthetic activity and it's translocation to promote better vegetative growth. Therefore, increased number of leaves per shoot with the spray of $\mathrm{GA}_{3}$. The findings are in agreement with result of Singh et al., (2011) and Kumar et al., (2014) in phalsa.

\section{Internodal length}

The internodal length was increased significantly with plant growth regulators. The maximum intermodal length $(11.5 \mathrm{~cm})$ was achieved with foliar spray of $\mathrm{GA}_{3} 150$ ppm followed by $\mathrm{GA}_{3}$ 100ppm (Table1).

Higher internodal length achieved might be due to cell division, cell elongation and growth enhancing properties of gibberellin as reported by Kumar et al., (2014) and Singh et al., (2015) in phalsa. Similar results has been reported by Alam and Kumar, (2017) and Singh et al., (2017) that maximum shoot length was observed in phalsa with foliar spray of GA150ppm.

\section{Number of fruiting nodes per shoot}

The maximum number of fruiting nodes per shoot (21.55) was counted on the plants with the spray of $\mathrm{GA}_{3} 150 \mathrm{ppm}$ followed by $\mathrm{GA}_{3}$ 100ppm (Table1). It might be possible because gibberellin causes vegetative growth for development of fruiting nodes.

Gibberellin and auxin helps in the translocation of carbohydrates and other metabolites for better reproductive growth of plants. These results are in close conformed with finding of Kumar et al., (2014) in phalsa. 


\section{Number of fruits per node}

The maximum number of fruits per node (20.76) was obtained with foliar spray of $\mathrm{GA}_{3}$ $150 \mathrm{ppm}$ followed with the spray of NAA 200ppm (Table1). The higher number of fruits per node might be due to fact that nitrogen is component of chlorophyll and gibberellic acid and auxin help in chlorophyll formation that regulate the build-up of proper $\mathrm{C}: \mathrm{N}$ ratio, which controls the flowering and fruiting of plants. It is also assumed that gibberellin and auxin play significant role in photosynthetic activity and better translocation of metabolites for developing fruit lets. These results are in close conformed with finding of Kumar et al., (2014) in phalsa. Similar results has been reported by Alam and Kumar, (2017) and Singh et al., (2017) that maximum shoot length was observed in phalsa with foliar spray of $\mathrm{GA}_{3} 150 \mathrm{ppm}$.

\section{Yield per plant}

Foliar spray of plant growth regulators significantly influenced fruit yield. The maximum fruit yield per plant $(4.85 \mathrm{~kg})$ was recorded with the spray of $\mathrm{GA}_{3} 100 \mathrm{ppm}$ followed by $\mathrm{GA}_{3}$ 150ppm (Table1). These results are in close conformed with finding of Grshtein, (1973) in orange, Sharma et al., (2008) in mango, Kaur et al., (2008) in Plum, Tripathi et al., (2009) in ber, Gill and Bal, (2011) in ber, Rohit, (2014) in mango, Anawal et al., (2015) in pomegranate and Rajput et al., (2015) in guava. The increase in the fruit yield due to $\mathrm{GA}_{3}$ treatment is due to increase in fruit set and fruit weight. The higher fruit yield might be due to $\mathrm{GA}_{3}$ mediating process for faster translocation and mobilization of stored metabolites or photosynthates from source to sink points (Krishnamoorthy, 1981 and Singh et al., 2003). Increased yield due to $\mathrm{GA}_{3}$ application of phalsa was also reported by Randhawa et al., (1959); Singh et al., (1966); Reddy,
(1977) and Singh et al., (1986). Debnath et al., (2011) also reported that phalsa bushes treated with $\mathrm{GA}_{3}$ at $100 \mathrm{ppm}$ produced significantly higher fruit yield. This may be due to the better physiology of developing fruits in terms of better supply of water and other compounds vital for their proper growth and development which resulted in improved size ultimately greater yield. These can be attributed to nature of gibberellins to increase to vegetative growth due to which more food material might be made available to the developing fruits. Kaur et al., (2018) reported that plants treated with $\mathrm{GA}_{3} 150 \mathrm{ppm}$ registered maximum fruityield in phalsa.

\section{Fruit length and Breadth}

Significantly highest fruit length $(1.60 \mathrm{~cm})$ and breadth $(1.72 \mathrm{~cm})$ were observed in $\mathrm{GA}_{3}$ $100 \mathrm{ppm}$ leads to maximum fruit size followed by $\mathrm{GA}_{3} 150 \mathrm{ppm}$ (Table1). Alam and Kumar (2017) and Kaur et al., (2018) reported that $\mathrm{GA}_{3} 150 \mathrm{ppm}$ significantly increased the fruit length and breadth of phalsa. The significant increment in fruit size over control by the use of gibberellins had been noticed and this increase might be due to the indirect effect of gibberellins on the level of auxins that ultimately caused cell elongation by enlargement of vacuoles and loosening of cell wall after increasing its palatability. Fruit length and breadth varied significantly due to various levels of $\mathrm{GA}_{3}$.

These finding are similar to the findings of Chundawat and Randhawa, (1973) in grape, Brahmchariand Rani, (2001) in litchi, Shukla et al., (2011) in aonla, Singh et al., (2011) in phalsa and Kundu et al., (2014) in pear and Chandra et al., (2015). These can be attributed to nature of gibberellins to increase to vegetative growth due to which more food material might be made available to the developing fruits, hence leads to increased fruit size. 


\section{Pulp weight}

Bushes treated with $\mathrm{GA}_{3}$ at $100 \mathrm{ppm}$ produced significantly higher pulp weight $(65.55 \mathrm{~g} / 100$ fruits $)$ over other treatments followed by $\mathrm{GA}_{3}$ at $150 \mathrm{ppm}(62 \mathrm{~g} / 100$ fruits) (Table1). On the other hand, minimum pulp weight was recorded $(45.11 \mathrm{~g} / 100$ fruits $)$ in control. Similarly, bushes treated with $\mathrm{GA}_{3}$ at $100 \mathrm{ppm}$ produced significantly higher pulp weight (Debnath et al., 2011).

The increase in the pulp weight may be due to the cell multiplication and cell enlargement or may be enhanced uptake of water and accumulation of sugar and other food reserves in greater amount as well as increased volume of intercellular spaces in the pulp of fruit due to $\mathrm{GA}_{3}$. This finding are in agreement with the earlier reports on this aspects by Khan et al., (1976), Singh and Lal, (1980) in litchi, Rani and Brahmachari, (2004) in mango. Prasad and Bajpai (1963) who also observed similar response of $\mathrm{GA}_{3}$ on phalsaplants. $\mathrm{GA}_{3} 150 \mathrm{ppm}$ treated plants gave fruits with maximum weight which might be due to the fact that gibberellins increase the cell division, cell enlargement and translocation of food material (Chandra et al., 2015).

\section{Stone weight}

Bushes treated with $\mathrm{GA}_{3} 100 \mathrm{ppm}$ produced fruits with significantly minimum stone weight $(10.22 \mathrm{~g})$ and maximum stone weight was recorded (20.50g) in control (Table2). $\mathrm{GA}_{3}$ were found effective in producing parthenocarpic fruits in multiseeded fruits but in single seeded fruits they reduced the size and weight of the seed. These results are in agreement with the findings of Rao and Rao, (1963) in phalsa, Islam and Siddique, (1973) in guava and Sharma and Dhillon, (1984) in litchi.

\section{Pulp to stone ratio}

Pulp stone ratio of fruit was recorded maximum with $\mathrm{GA}_{3} 100 \mathrm{ppm}$ (37.89) followed by $\mathrm{GA}_{3} 100 \mathrm{ppm}$ (Table2). Similarly, phalsa bushes treated with $\mathrm{GA}_{3}$ at $100 \mathrm{ppm}$ produced fruits with significantly higher pulp to stone ratio (Debnath et al., 2011). It may be due to the involvement of $\mathrm{GA}_{3}$ to increase the cell division, growth and translocation of food material which might be responsible to improve the weight of fruits. These findings are supported by the results of Kacha et al., (1914) in phalsa and Chandra et al., (1915) in aonla fruits and Singh et al., (2015) in phalsa.

\section{Total soluble solids}

Significantly higher content of TSS $\left(27.50^{\circ}\right.$ Brix $)$ was obtained when the bushes were sprayed with ethrel $500 \mathrm{ppm}$ followed by ethrel $750 \mathrm{ppm}$. Similar results are reported by Debnath et al., (2011) with ethrel $500 \mathrm{ppm}$ in phalsa. Increased in the TSS by ethrel may be due to quick metabolic transformation of starch and pectin into soluble compounds and rapid translocation of sugars from the leaves to the developing fruits (Tripathi and Sukhla, 2007). Similar finding was also reported by Rema and Sharma, (1991) in phalsa. Kaur et al., (2018) reported that significantly higher TSS was observed in phalsa fruits obtained from plants treated with ethrel $1000 \mathrm{ppm}$.

\section{Acidity}

Ethrel $500 \mathrm{ppm}$ was more effective in reducing acidity $(2.30 \%)$. Similar results have been reported by Kaur et al., (2018) in phalsa with ethrel 500ppm. The acidity of the fruit under the influence of growth regulators applied declined because it might have converted fastly into sugar and their derivatives (Kumara et al., 2007) or due to faster degradation of organic acids (Dutta $e t$ al., 2008). Prasad, (1990) also reported 
similar results with $\mathrm{GA}_{3}$ in phalsa and Sharma and Dhillon, (1984) in litchi. Significantly lower titratable acidity was noticed with foliar spray of $\mathrm{GA}_{3} 100 \mathrm{ppm}$ in phalsa (Debnath et al., 2011). Kaur et al., (2018) observed that fruits with minimum acidic content were obtained from plants treated with ethrel 1000 ppm.

\section{TSS: Acidity}

Maximum TSS: acidity ratio (11.96) has been reported by ethrel $500 \mathrm{ppm}$ followed by $\mathrm{GA}_{3}$ 750ppm. Kaur et al., (2018) reported maximum TSS: acidity ratio with ethrel1000ppm.Maximum TSS: acidity ratio was also observed with $\mathrm{GA}_{3} 100 \mathrm{ppm}$ followed by ethrel $250 \mathrm{ppm}$ (Debnath et al., 2011). This might be due to early and rapid degradation of acid and its conversion into sugars (Kumara et al., 2007). This is in conformity with the findings of Thilak, (1980) in Thompson seedless and Mohammed and Hulamani, (2001) in Arkavati grapes.

Table.1 The effect of foliar feeding of plant growth regulators on growth and fruiting behaviour of Phalsa

\begin{tabular}{|c|c|c|c|c|c|c|c|c|c|c|}
\hline Treatments & $\begin{array}{c}\text { Number of } \\
\text { shoots per } \\
\text { plant }\end{array}$ & $\begin{array}{c}\text { Shoot } \\
\text { length } \\
\text { (m) }\end{array}$ & $\begin{array}{c}\text { Leaves } \\
\text { per } \\
\text { shoot }\end{array}$ & $\begin{array}{l}\text { Internodal } \\
\text { length }(\mathrm{cm})\end{array}$ & $\begin{array}{c}\text { Number } \\
\text { of fruiting } \\
\text { nodes per } \\
\text { shoot }\end{array}$ & $\begin{array}{c}\text { Number } \\
\text { of fruits } \\
\text { per } \\
\text { Node }\end{array}$ & $\begin{array}{l}\text { Yield } \\
\text { per } \\
\text { plant } \\
(\mathbf{k g})\end{array}$ & $\begin{array}{r}\text { Fruit } \\
\text { length } \\
(\mathrm{cm})\end{array}$ & $\begin{array}{c}\begin{array}{c}\text { Fruit } \\
\text { breadth } \\
(\mathrm{cm})\end{array} \\
\end{array}$ & $\begin{array}{c}\text { Pulp } \\
\text { weight }\end{array}$ \\
\hline NAA 25ppm & 95.12 & 2.35 & 56.12 & 8.55 & 15.15 & 15.00 & 3.72 & 0.96 & 1.18 & 55.52 \\
\hline NAA 50ppm & 97.00 & 2.50 & 59.21 & 8.75 & 16.00 & 15.50 & 4.00 & 1.05 & 1.26 & 58.12 \\
\hline NAA 75ppm & 10.24 & 2.91 & 62.00 & 9.15 & 16.52 & 16.10 & 3.85 & 0.98 & 1.20 & 56.00 \\
\hline $\mathrm{GA}_{3}$ 50ppm & 100.15 & 3.00 & 63.11 & 9.50 & 16.71 & 15.00 & 4.25 & 1.15 & 1.33 & 59.52 \\
\hline $\mathrm{GA}_{3} 100 \mathrm{ppm}$ & 115.50 & 3.50 & 66.00 & 10.00 & 18.10 & 17.12 & 4.85 & 1.60 & 1.72 & 65.55 \\
\hline $\mathrm{GA}_{3}$ 150ppm & 130.25 & 4.15 & 72.50 & 11.50 & 21.55 & 20.76 & 4.52 & 1.25 & 1.46 & 62.00 \\
\hline $\begin{array}{l}\text { Kinetin } \\
\text { 15ppm }\end{array}$ & 85.53 & 2.10 & 48.15 & 8.12 & 14.10 & 13.51 & 3.30 & 0.93 & 1.14 & 52.00 \\
\hline $\begin{array}{l}\text { Kinetin } \\
\text { 30ppm }\end{array}$ & 88.00 & 2.15 & 50.00 & 8.52 & 14.50 & 13.11 & 3.52 & 0.95 & 1.17 & 54.52 \\
\hline $\begin{array}{l}\text { Kinetin } \\
\text { 45ppm }\end{array}$ & 91.55 & 2.30 & 53.55 & 9.00 & 14.54 & 14.00 & 3.40 & 0.94 & 1.16 & 53.12 \\
\hline $\begin{array}{l}\text { Ethrel } \\
\text { 250ppm }\end{array}$ & 81.12 & 1.85 & 43.12 & 6.52 & 12.00 & 11.12 & 1.50 & 0.90 & 1.11 & 49.22 \\
\hline Ethrel 500pm & 83.15 & 1.90 & 45.15 & 7.00 & 12.50 & 12.00 & 2.00 & 0.92 & 1.13 & 51.00 \\
\hline $\begin{array}{l}\text { Ethrel } \\
\text { 750ppm }\end{array}$ & 85.00 & 2.00 & 47.00 & 7.55 & 13.12 & 12.60 & 1.75 & 0.91 & 1.12 & 50.15 \\
\hline $\begin{array}{l}\text { Water spray } \\
\text { (control) }\end{array}$ & 80.00 & 1.80 & 40.00 & 6.00 & 11.00 & 10.00 & 2.50 & 0.84 & 1.06 & 45.11 \\
\hline CD (5\%) & 2.93 & 0.83 & 3.37 & 1.99 & 2.10 & 2.20 & 0.80 & 0.40 & 0.06 & 3.35 \\
\hline
\end{tabular}


Table. 2 The effect of foliar feeding of plant growth regulators on fruit quality of Phalsa

\begin{tabular}{|c|c|c|c|c|c|c|c|c|c|c|}
\hline Treatments & $\begin{array}{l}\text { Stone } \\
\text { weight }\end{array}$ & $\begin{array}{l}\text { Pulp: } \\
\text { Stone }\end{array}$ & $\begin{array}{l}\text { TSS } \\
\left({ }^{\circ} \text { Brix }\right)\end{array}$ & $\begin{array}{l}\text { Titratable } \\
\text { acidity } \\
(\%)\end{array}$ & $\begin{array}{l}\text { TSS: } \\
\text { Acidity }\end{array}$ & $\begin{array}{l}\text { Total } \\
\text { sugars } \\
(\%)\end{array}$ & $\begin{array}{l}\text { Reducing } \\
\text { sugars } \\
(\%)\end{array}$ & $\begin{array}{l}\text { Non- } \\
\text { reducing } \\
\text { sugars } \\
(\%)\end{array}$ & $\begin{array}{l}\text { Ascorbic } \\
\text { acid } \\
\text { (mg/100g } \\
\text { of pulp) }\end{array}$ & $\begin{array}{l}\text { Shelf life } \\
\text { (hours) }\end{array}$ \\
\hline NAA 25ppm & 14.62 & 35.07 & 22.25 & 2.800 & 7.950 & 24.15 & 18.50 & 5.65 & 39.00 & 45.25 \\
\hline NAA 50ppm & 13.20 & 34.66 & 24.00 & 2.600 & 9.230 & 25.00 & 19.00 & 6.00 & 41.00 & 46.50 \\
\hline NAA75ppm & 14.00 & 35.00 & 23.15 & 2.720 & 8.510 & 22.55 & 18.75 & 5.80 & 40.00 & 45.00 \\
\hline GA $_{3}$ 50ppm & 12.52 & 36.02 & 23.65 & 2.540 & 9.310 & 24.35 & 18.60 & 5.75 & 41.50 & 47.52 \\
\hline $\mathrm{GA}_{3}$ 100ppm & 10.22 & 37.89 & 25.00 & 2.480 & 10.080 & 26.35 & 19.85 & 6.50 & 44.25 & 50.45 \\
\hline $\mathrm{GA}_{3}$ 150ppm & 11.00 & 36.50 & 24.85 & 2.500 & 9.940 & 25.05 & 18.80 & 6.25 & 42.22 & 48.00 \\
\hline Kinetin 15ppm & 17.20 & 34.60 & 21.25 & 4.200 & 5.060 & 23.90 & 18.30 & 5.60 & 36.00 & 51.42 \\
\hline Kinetin 30ppm & 15.00 & 34.76 & 22.50 & 3.800 & 5.920 & 24.32 & 18.52 & 5.80 & 38.55 & 53.51 \\
\hline Kinetin 45ppm & 15.52 & 34.32 & 22.00 & 4.000 & 5.500 & 24.15 & 18.45 & 5.70 & 37.12 & 52.00 \\
\hline Ethrel 250ppm & 18.50 & 33.86 & 26.32 & 2.420 & 10.880 & 25.35 & 18.85 & 6.50 & 32.11 & 42.00 \\
\hline Ethrel 500pm & 16.25 & 33.63 & 27.50 & 2.300 & 11.960 & 29.00 & 21.50 & 7.50 & 34.45 & 39.00 \\
\hline Ethrel 750ppm & 17.00 & 33.58 & 26.25 & 2.360 & 11.290 & 26.33 & 19.33 & 7.00 & 33.00 & 35.00 \\
\hline $\begin{array}{l}\text { Water spray } \\
\text { (control) }\end{array}$ & 20.50 & 32.81 & 20.00 & 4.800 & 4.170 & 21.50 & 17.00 & 4.50 & 28.75 & 30.00 \\
\hline CD (5\%) & 3.49 & 2.62 & 2.02 & 0.571 & 1.612 & 2.699 & 1.698 & 1.416 & 3.25 & 3.072 \\
\hline
\end{tabular}

Reducing sugars, Non-reducing sugars and Total sugars

Maximum content of reducing sugars $(21.5 \%)$, non-reducing sugars $(7.5 \%)$ and total sugars $(29 \%)$ were observed in ethrel treatment $500 \mathrm{ppm}$. Present finding was confirmed with the findings of Remaand Sharma., (1993) with ethrel in phalsa. Kaur et al., (2018) showed that phalsa plants treated with ethrel $1000 \mathrm{ppm}$ yielded fruits with maximum reducing sugars and total sugars. This might be due to that ethrel promoted hydrolysis of starch into sugars (Kacha et al., 2014). The present results are in conformity with the findings of Singh et al., (2011) and Meitei et al., (2013). Increased in reducing sugar with $\mathrm{GA}_{3} 150$ ppmin phalsa was reported by Debnath et al., (2011). Increased in reducing sugar with higher concentration of GA $_{3}$ was reported by Prasad, (1990) in phalsa,
Phaniprasasd, (1980) in guava and Thilak, (1980) in Thompson Seedless grapes. Gibberellins have been shown to act through auxin synthesis. Therefore, the exogenous application of $\mathrm{GA}_{3}$ might have supplemented the endogenous auxin and causes greater influx of sugars in the fruits (Mohammed and Hulamani, 2001).

\section{Ascorbic acid}

Maximum ascorbic acid content in phalsa fruits (44.25 $\mathrm{mg} / 100 \mathrm{gm}$ of pulp) was observed with $\mathrm{GA}_{3} 100 \mathrm{ppm}$. Similar results have been reported by Kaur et al., (2018) with $\mathrm{GA}_{3} 100 \mathrm{ppm}$ in phalsa. Maximum ascorbic acid content in fruit juice was noticed with $\mathrm{GA}_{3} 150$ ppm (Alam and Kumar, 2017). The increase in ascorbic acid content may be attributed to quality improving properties of $\mathrm{GA}_{3}$ is assigned the role of quality nutrient 
and may help in synthesis of ascorbic acid in developing fruits. The result is in consonance with the findings of Kher et al., (2005) in guava, Kacha et al., (2014) in phalsa and Rokaya et al., (2016) in mandarin.

\section{Shelf life}

Highest shelf life $(53.51 \mathrm{hr})$ of phalsa fruits was recorded with kinetin 30 ppm. Similarly, highest shelf life of phalsa fruits was recorded with kinetin 30 ppm (Debnath et al., 2011). The increased in the shelf life due to kinetin application may be attributed to efficacy of kinetin to increase endogenous kinetins, stimulates protein synthesis as well as nucleic acid synthesis thereby delaying the senescence and reduce the physiological loss of weight during storage. Similar results were reported by earlier worker in grapes (Dedolph et al., 1961; Randhawa et al., 1976 and Dhillon, 1985) and apple (Mir et al., 1996).

\section{References}

A.O.A.C. 1980.Official and tentative methods of analysis. Association of official agricultural chemists.14th Ed., Washington, D.C.

Alam, T. and Kumar, A. 2017. Effect of $\mathrm{GA}_{3}$ on growth, yield and quality of phalsa (Grewia subinequalis D. C.). Plant Archives. 17 (1): 608-610.

Ali, H.S., Ghaffor, A., Waseem, K. and Nadeem, M. 2001. Growth and yield response of phalsa (Grewia asiatica L.) to various pruning intensities and dates. Journal of Biological Sciences.1: 548550.

Anawal, V.V., Narayanaswamy, P. and Ekabot, S.D. 2015. Effects of plant growth regulators on fruit set and yield of pomegranate $\mathrm{cv}$. Bhagwa. International Journal of Scientific Research. 4 (9): 220222.

Brahmchari, V.S. and Rani, R. 2001. Effect of growth substances on cracking and other physio-chemical composition of litchi. Orissa Journal of Horticulture. 29 (1): 41-45.

Chandra, R., Manju, R. and Singh, K.K. 1915. Effect of foliar application of various growth regulators on yield and quality of aonla cv. NA-7.International Journal of Tropical Agriculture, 33 (3): JulySeptember.

Chandra, R., Rawat, M., Singh, S.S. and Singh, K.K. 2015.Effect of foliar application of various growth regulators on yield and quality of Aonla cv.NA-7. National Academy Agricultural Science 33:21232127.

Chundawat, B. S. and Randhawa, G.S.1973. Effect of plant growth regulator on fruit set, drop and quality of grape fruit (Citrus paradisi L.) Saharanpur special. Indian Journal of Horticulture 29 (3-4): 277282.

Debnath, A., Vanajalatha, K., Momin, U. and Reddy, U. 2011. Effect of NAA, GA 3 , kinetin and ethrel on yield and quality in phalsa (Grewia subinaequalis DC). The Asian Journal of Horticulture. 6 (2): 474477.

Dedolph, R.R., Wittmer, S.H. and Tuli V.1961. Senesecence inhibition and respiration. Science.134: 1075.

Dhillon, B.S., Ladania, M.S. and Bhkulllar, J.S.1985. Improvement of Beauty seedless grapes with plant growth regulators. Indian Journal of Horticulture. 30: 366-369.

Dutta, P., Singha, S., Kundu, S. and Das, B.C. 2008.Effect of growth regulators on physiochemical qualities of Carambola (sweet type). Orissa Journal of Horticulture 36 (1) 44-48.

Eel Kim, M.Y., Ho Kim., Kho, C.M. and Sang Ook.2003. Effects of foliar application of $\mathrm{GA}_{3}$ on flowering and fruit quality of very early maturing satsuma mandarin. Korean Journal of Horticultural Science and Technology. 21 (2): 110-113.

Gill, K.S. and Bal, J.S.2011. Impact of application of growth regulators on Indian jujube. International Jujube Symposium. 
993:119-124.

Grshtein, L.A.1973. Studies on the effect of gibberellins on citrus fruit set and quality subicheckeal no. 4:18-82.

Islam, M.M. and Siddique.1973.A study on the induction of parthenocarpic guava by $\mathrm{GA}_{3}$.Bangladesh Horticulture. 1:31-36.

Kacha, H.L., Jat, G. and Patel, S.K. 2014. Performance of various plant growth regulators on yield and quality of phalsa (Grewia asiatica L.). Hort Flora Research Spectrum. 3 (3): 292-294.

Kacha, H.L., Viradia, R.R., Leua, H.N., Jat, G. and Tank, AK.2012. Effects of NAA, $\mathrm{GA}_{3}$ and ethrel on yield and quality of phalsa under southsurashtra condition. Asian Journal of Horticulture 7: 242-245.

Kaur, G., Singh, M. and Singh, M.2018. Influence of bio-regulators on the fruit quality and yield attributes of phalsa (Grewia subinaequalis DC). Journal of Experimental Agriculture International. 21 (3): 1-6

Kaur, H., Singh, A., Gupta, M. and Randhawa, J.S.2008. Effect of NAA and gibberellic acid on preharvest fruit drop and quality of Satluj Purple plum.Haryana Journal of Horticultural Sciences. 37:31-32.

Khan, I., Misra, R. S. and Srivastava, R. P.1976.Effect of plant growth regulators on the fruit drop, size and quality of litchi (cv. Rose scented). Progressive Horticulture. 8 (2): 61-69.

Kher, R., Bhat, S. and Wali, V.K. 2005. Effect of foliar application of $\mathrm{GA}_{3}$, NAA and $\mathrm{CCC}$ on physico-chemical characteristics of guava cv. Sardar. Haryana Journal of Horticultural Sciences 34 (1/2): 31-32.

Krishnamoorthy, H.N.1981. Gibberellins. Plant growth substances: 77-87.

Kumar, S., Yadav, A.L., Vishwakarma, G. and Yadav, D.K. 2014. Effect of foliar feeding of nutrients and plant growth regulators on vegetative growth and yield of phalsa (Grewia subinequalis D.C.). Research in environment and life sciences.7 (4): 293-294.

Kumara, K. and Abhay, M. and Jayant, S. 2007. Effect of growth substances on yield and quality of mango cv. Langra. Orissa Journal of Horticulture. 35 (1): 67-70.

Kundu, M., Joshi, R., Rai, P.N. and Bist, L.D. 2014. Effect of bio-regulators on fruit growth, quality and productivity of pear (Pyrus pyrifolia) cv. Gola under tarai condition. Journal of Applied Horticulture. 15 (2): 106-109.

Meitei, S.B., Patel, R.K., Deka, B.C., Deshmukh, N.A. and Singh, A.2013. Effect of chemical thinning on yield and quality of peach cv. Flordasun. African Journal of Agricultural Research. 8:35583565.

Mir, N.A., Dalal, M.A., Bhat, A.R. and Ganaie, R.D.1996. Effect of pre-harvest spray of calcium and growth regulators on physico-chemical characteristics in relation to length of storage in apple. Indian Journal of Plant Physiology.1: 5253

Mohammed, F. and Hulamani, N.C. 2001.Effect of growth regulators and boric acid and their stage of treatments on berry quality of Arkavati grapes. Karnataka Journal of Agricultural Sciences. 14 (3): 849-852.

Phani Prasad, P. 1980. Studies on floral biology and improvement in yields of seedless guava by selection of pollinizers and use of growth regulators. M.Sc. (Ag.) Thesis, APAU, Rajendranagar, Hyderabad, A.P. (India).

Prasad, A. and Bajpai, P.N.1963. Effect of alpha naphthalene acetic acid on fruit set, size, ripening and yield of phalsa (cv. Sarbati). Kanpur Agriculture College Journal. 22:59-61.

Prasad, Y. V. S. 1990. Effect of NAA, GA 3 and miraculam on yield and quality of phalsa. M.Sc (Ag) Thesis, APAU, Rajendranagar, Hyderabad, A.P. (India).

Pujari, S.2015. Phalsa cultivation in IndiaProduction area, Climate, Harvesting and Fruit handling.

Rajput, R.P., Senjaliya, H.J., Vala, G.S. and Mangroliya, G.S. 2015.Effect of various plant growth regulators on yield and quality of guava (Psidium guajava L.) cv. Lucknow 49.International Journal of 
Agricultural Sciences.11 (1): 179-182.

Randhawa, G.S., Dhillon, B.S. and Mann, S.S.1976. Effect of application of CCC and kinetin on storage of perlette grapes.Journal of Research Punjab Agricultural University.13:267-272.

Randhawa, G.S., Mallik, R.S. and Singh, H.P. 1967. Effect of certain growth regulators on yield and quality of phalsa. Indian Journal of Horticulture. 18: 46-50.

Randhawa, G.S., Singh, J.P. and Khanna, S.S. 1959. Effect of gibberellic acid and some other plant growth regulators on fruit set, size, total yield and quality of phalsa (Grewia asiatica L.). Indian Journal of Horticulture. 16: 202-205.

Rani, R. and Brahmachari, V.S. 2004.Effect of growth substances and calcium compounds on fruit retention, growth and yield of Amrapali mango. Orissa Journal of Horticulture 32 (1): 15-18.

Rao, S.N. and Rao, C.H.S.1963. Studies on the effect of gibberellic acid and some other growth regulators on phalsa (Grewia asiatica L). South Indian Journal of Horticulture. 11:31-36.

Reddy, S. A. 1977. Studies on the action of gibberellic acid and naphthalene acetic acid on fruit set, yield and quality of fruit of phalsa (Grewia asiatica L.). M.Sc. (Ag.) Thesis, Andhra Pradesh Agricultural University, Rajendranagar, Hyderabad, A.P. (India).

Rema, J. and Sharma, V.P. 1991. Effect of growth regulators on yield and quality of phalsa (Grewia subinaequalis D.C). South Indian Journal of Horticulture. 39 (6): 327-331.

Rema, J. and Sharma, V.P.1993. Chemicals as an aid for mechanical harvesting in phalsa (Grewia subinaequalis D.C). South Indian Journal of Horticulture 41 (1): 813.

Rohit, S. 2014. Effect of $\mathrm{GA}_{3}$ and urea spray on flowering fruit retention and fruit quality of mango cv. Langra. Doctoral dissertation, JNKKV.

Rokaya, P. R., Baral, D.R., Gautam, D.M., Shrestha, A.K. and Paudal, K.P. 2016.
Effect of pre-harvest application of gibberellic acid on fruit quality and shelf life of mandarin (Citrus reticulata B.). American Journal of Plant Sciences. 7: 17.

Salunkhe, D.K. and Desai, B.B.1984. Phalsa. In: Salunkhe and Desai (eds.), Postharvest biotechnology of fruits. Vol. 2.CRC Press, Boca Raton, FL, pp 129.

Sharma, J.R., Bhatia, S.K., Gupta, R.B., Singh, S. and Gehlot, R. 2008. Influence of nutrients and growth regulators on yield and quality of ber (Ziziphus mauritiana Lamk.) fruits cv. Umran. Haryana Journal of Horticultural Sciences. 37 (3/4): 217-219.

Sharma, S.B. and Dhillon, B.S. 1984. Effect of $\mathrm{ZnSO}_{4}$ and plant growth regulators on fruit retention, fruit weight and quality of litchi (Litchi chinensis Sonn.). Journal of Research Punjab Agricultural University. 24:235-239.

Shukla, H.S., Kumar, V. and Tripathi, V.K. 2011.Effect of gibberellic acid and boron on development and quality of aonla fruit "Banarasi". ISHS ActaHorticulturae. 890:375.

Singh, A. K., Singh, R. and Mann, S.S. 2003. Effect of plant bio regulators and nutrients on fruit set, yield and quality of pear cv. Le Conte. Indian Journal of Horticulture. 60:34-39.

Singh, A.K., Kumar, A. and Yadav, A.L. 2015. Effect of pruning intensity, foliar feeding of P.G.R. and micro nutrients on physicochemical attributes of phalsa (Grewia subinaequalis D.C.) fruits. Research in Environment and Life Sciences. 8 (4): 675-678.

Singh, B., Yadav, A.L. and Meena, A.K. 2017.The Effect of foliar feeding of plant growth regulators on growth and fruiting behavior of phalsa. International Journal of Agriculture Innovations and Research. 5 (5): 806-808

Singh, J. P., Kumar, S., Katiyar, P.N. and Dwivedi, A.K. 2011. Effect of calcium nitrate, $\mathrm{GA}_{3}$ and ethrel on fruiting, ripening and chemical traits of phalsa 
(Grewia subinequalis D. C.). Annals of Horticulture. 12 (1): 72-76.

Singh, K.K., Nijjar, G.S. and Bhathal, G.S. 1966. Effect of GA and 2, 4, 5-T on the fruitset, size and yield of phalsa. Journal of Research Punjab Agricultural University. 3: 286-290.

Singh, M., Gautam, R.K.S. Prasad, Y. and Singh, A.K. 1986. Studies on the effect of plant growth regulators and their different concentration on yield and quality of phalsa (Grewia subinaequalis). Haryana Journal of Horticultural Sciences. 15: 196-199.

Singh, M., Gautam, R.K.S., Prasad, Y. and Singh, A.K. 1986.Studies on the effect of plant growth regulators and their different concentration on yield and quality of phalsa (Grewia subinaequalis). Haryana Journal of Horticultural Sciences. 15: 196-199.

Singh, S., Bansal, M.L., Singh, T.P. and Kumar, P.1998.Statistical Methods for Research Workers. Kalyani Publishers, New Delhi.

Singh, S.K. and Singh, H.K. 2008. Pruning behavior in aonla (Emblica officinalis Gaertn.) cv Narendraaonla. Environ and
Ecol. 26: 1039-1041.

Singh, U. S. and Lal, R.K. 1980. Influence of growth regulators on setting, retention and weight of fruits in two cultivars of litchi. Scientia Horticulturae.12:312-326.

Thilak, K.S. 1980. Effect of $\mathrm{GA}_{3}$ on development and quality of berries of grape cv. Thompson Seedless. Journal of Research Punjab Agricultural University. 9: 64-66.

Tripathi, D., Pandey, A.K., Pal, A.K. and Yadav MP. 2009. Studies on effect of plant growth regulators on fruit drop, development, quality and yield of ber cv. Banarasi Karaka. Progressive Horticulture. 41:184-186.

Tripathi, V. K. and Shukla, P.K. 2007.Effect of plant bioregulators, zinc sulphate and boric acid on yield and quality of strawberry cv. Chandler. The Asian Journal of Horticulture. 4 (1) 15-18.

Zeeshan, M. and Singh J.P. (2017). Studies on effect of foliar application of boron and $\mathrm{GA}_{3}$ on growth, fruiting and yield of phalsa (Grewia subinaequalis D.C.). Hort Flora Research Spectrum. 6 (4): 273-277.

\section{How to cite this article:}

Sukhjit Kaur. 2020. Effect of Foliar Feeding of Plant Growth Regulators on Vegetative Growth, Yield and Quality of Phalsa (Grewia subinaequalis DC). Int.J.Curr.Microbiol.App.Sci. 9 (06): 3209-3220. doi: https://doi.org/10.20546/ijcmas.2020.906.384 